\title{
PARTIAL RETRACTION
}

The Editorial Board announces the formal publication of partial retraction of the article:

Borges SS, Ramos AFPL, Moraes Filho AV, Braga CASB, Carneiro LC, Barbosa MS. Prevalence of Helicobacter pylori infection in dyspeptic patients and its association with clinical risk factors for developing gastric adenocarcinoma. Arq Gastroenterol. 2019,56(1):66-70. doi: http://dx.doi.org/10.1590/ s0004-2803.201900000-03.

The galley proof is based on the authors' commitment to ensuring the whole article conference.

In the last paragraph of DISCUSSION, a passage that was not part of the file was erroneously published.

Ricardo Guilherme Viebig, MD.

Editor in chief 


\title{
Prevalence of Helicobacter pylori infection in dyspeptic patients and its association with clinical risk factors for developing gastric adenocarcinoma
}

\author{
Stéfani Sousa BORGES ${ }^{1}$, Amanda Ferreira Paes Landim RAMOS ${ }^{1}$, Aroldo Vieira de MORAES FILHO², \\ Carla Afonso da Silva Bitencourt BRAGA ${ }^{1,3}$, Lilian Carla CARNEIRO ${ }^{3}$ and Mônica Santiago BARBOSA ${ }^{1,3}$
}

\begin{abstract}
Background - In Brazil, particularly in the underdeveloped localities, the prevalence of Helicobacter pylori (H. pylori) infections can range up to $90 \%$. These rates are higher in older individuals and vary by country region. H. pylori infections are linked to the development of gastric pathologies, namely mild to moderate gastritis, gastroenteritis, peptic ulcer, intestinal metaplasia, and gastric cancer. In 1994, this organism was classified by the International Agency for Research on Cancer (IARC) as pertaining to the Group 1 carcinogen for gastric adenocarcinoma etiology. Gastric cancer represents a significant public health problem, being the fourth most common malignant tumor and the second largest cause of cancer-related deaths. Objective - To investigate the prevalence of H. pylori infection in dyspeptic patients and determine the link between clinical risk factors and gastric adenocarcinoma diagnosis. Methods - Polymerase chain reaction (PCR) analysis was employed for molecular diagnosis of gastric tissue biopsies collected from 113 dyspeptic patients at the University Hospital of Federal University of Goiás. Molecular analyses allowed the identification of H. pylori infections. Furthermore, histopathological examinations were performed to determine the clinical risks of developing gastric malignancies. Results - The test results identified 69 individuals older than 44 years, from 75 (66.4\%) positive $H$. pylori infection samples. The prevalence of gastric adenocarcinoma in this study was 1.3\%. Among the infected patients, six (8.2\%) had high risk, and $67(91.8 \%)$ had a low risk of developing gastric cancer $(P<0.05)$. Conclusion - This study shows a high prevalence of $H$. pylori infection and identifies its contribution to gastric inflammations, which in the long term are manifested in high-risk clinical factors for the development of gastric adenocarcinoma.
\end{abstract}

HEADINGS - Dyspepsia. Stomach neoplasms. Gastrointestinal diseases. Bacteria.

\section{INTRODUCTION}

Helicobacter pylori (H. pylori) is a spiral, gram-negative, microaerophilic and fastidious microorganism. This bacterium exhibits two to six helix flagella, it grants high motility and support for penetrating the human gastric mucosa ${ }^{(1,2)}$.

The prevalence of infections by $H$. pylori is highly variable, owing to its geographical distribution and host's ethnicity, age, sex and socioeconomic factors ${ }^{(3)}$. It is estimated that half of the world's population is infected by this organism ${ }^{(1)}$. Indeed, infection rates are significantly lower in the developed countries $(20 \%)$ compared with locations where sanitation conditions are underdeveloped $^{(4)}$.

In Brazil, the prevalence of $H$. pylori infection can range up to $90 \%$ in more impoverished areas ${ }^{(5)}$. These indices are higher in older populations and are region specific, which confirms that economic status and hygiene are risk factors for H. pylori infection ${ }^{(6)}$.
The exact transmission mode of this bacterium remains to be understood. However, it is known that this organism colonizes the gastric mucosa, suggesting that the infection occurs through the gastro-oral, oral-oral, fecal-oral routes ${ }^{(1,7)}$ or by zoonotic transmission. For instance, domestic flies have zoonotic potential mainly due to its contact with decomposing organic matter and contaminated feces, which supports their proliferation to subsequently infect humans, animals and plant hosts ${ }^{(8,9)}$.

The risk factors for $H$. pylori infection are $\operatorname{sex}^{(10)}$, age ${ }^{(11,12)}$, smoking ${ }^{(13)}$, alcohol consumption ${ }^{(14)}$, contaminated food ${ }^{(12)}$, untreated water intake ${ }^{(5)}$, family size ${ }^{(15)}$, bed sharing ${ }^{(16)}$, poor living conditions in childhood ${ }^{(17)}$, educational ${ }^{(13)}$ and socioeconomic level ${ }^{(18)}$, hygiene ${ }^{(19)}$, and family medical history of gastric disease $\mathrm{e}^{(11)}$.

H. pylori infection is primarily observed in children and may remain asymptomatic until adulthood ${ }^{(20)}$. At this stage, the infection provokes abdominal pain ${ }^{(5)}$, anorexia ${ }^{(21)}$, gastrointestinal bleeding, and antral modularity ${ }^{(16)}$.

Declared conflict of interest of all authors: none

Disclosure of funding: no funding received

Research performed at: Instituto de Patologia Tropical e Saúde Pública, Universidade Federal de Goiás, Goiânia, GO, Brasil.

1 Universidade Federal de Goiás, Faculdade de Farmácia, Goiânia, GO, Brasil. ${ }^{2}$ Universidade Federal de Goiás, Instituto de Ciências da Saúde, Programa de Pós-Doutorado em Ciências da

Saúde, Goiânia, GO, Brasil. ${ }^{3}$ Universidade Federal de Goiás, Instituto de Patologia Tropical e Saúde Pública, Goiânia, GO, Brasil.

Corresponding autor: Mônica Santiago Barbosa. E-mail: santiagosant@gmail.com 
The development of gastric pathologies is directly associated with $H$. pylori infection, which induces mild to moderate gastritis $^{(5)}$, gastroenteritis and peptic ulcer ${ }^{(10)}$. These conditions often lead to intestinal metaplasia ${ }^{(22)}$, and gastric cancer ${ }^{(23)}$. Therefore, in 1994, H. pylori was classified as Group 1 carcinogen for Gastric Adenocarcinoma by the IARC ${ }^{(24)}$.

Gastric adenocarcinoma accounts for $90 \%$ of gastric cancer cases ${ }^{(21)}$. This cancer type represents a significant health issue, being the fourth most common malignant tumor and the second largest cause of cancer related deaths ${ }^{(25)}$.

The diagnosis of gastric adenocarcinoma is rarely detected at early stages. Consequently, most patients exhibit metastatic lesions when first diagnosed ${ }^{(26,27)}$. If untreated, $63 \%$ of cases progress to incurable disease within five years ${ }^{(24)}$.

Gastric cancer screening consists of two phases, namely primary prevention (identifying possible risk factors) and secondary screening method (early detection) ${ }^{(28)}$. In Japan younger than 20 years are screened with primary prevention methods to identify and treat $H$. pylori infection. On the other hand, individuals aged 50 years or more are tested with the combination of the two method through endoscopic examination. Since its implementation in 2013, this plan significantly reduced the incidence, mortality and annual cost for gastric cancer treatment in Japan ${ }^{(29)}$.

By determining the relevance of preventing $H$. pylori infections for public health costs, this study aimed to investigate the prevalence of this organism in dyspeptic patients. Moreover, we aimed to evaluate the link between the infection and clinical risk factors for gastric cancer development. Our findings may contribute to emerging public prevention and treatment policies for cancer in Brazil.

\section{METHODS}

\section{Ethical considerations}

The study protocol was approved by the Research Ethics Committee of the University Hospital (CAAE): 83422017.7.0000.5078, published under the number 2.519.032, according to the Resolution CNS 196/96. All patients enrolled in this study signed an Informed Consent Form.

The age bar for patients enrolled in the study was above 18 years. Subjects treated with proton pump inhibitors or blocking agents (one week before endoscopy) and immunosuppressants or antibiotic (eight weeks before of endoscopy) were excluded from our study. Moreover, we also excluded individuals presenting active gastrointestinal bleeding, pregnancy and those with inability to undergo endoscopy.

\section{Patients}

Were investigated 113 dyspeptic patients submitted to endoscopic examination at the University Hospital. During the endoscopy three fragments of the antrum and the gastric body of each patient were collected. One fragment was submitted to molecular diagnosis (polymerase chain reaction - PCR), and the other two were submitted to histopathological examination.

\section{Risk criteria}

The endoscopy results were stratified according to the risk of developing gastric adenocarcinoma. Patients exhibiting gastric atrophy and intestinal metaplasia were classified as high risk for gastric cancer diagnosis. Conversely, patients with normal endoscopy result, esophagitis, duodenitis, gastritis, ulcer, and xanthelasma $^{(30)}$ were categorized as low risk.

\section{DNA extraction}

DNA extraction was performed at the Laboratory of Biotechnology of Microorganisms of the Federal University of Goiás through KitQIamp DNA minikit ${ }^{\circledR}$ (Qiagen, Valencia, CA, United States). Ten $\mu \mathrm{L}$ aliquot of each sample were used for DNA quantification and purity analysis with NanoDrop ${ }^{\circledR}$ (ND-1000 UV-Vis).

\section{PCR}

Genomic DNA was amplified by PCR following previously described protocols by Nevoa et al. (2017). Molecular detection of $H$. pylori was performed by amplifying the $16 \mathrm{~S}$ ribosomal gene (rRNA) using the HpX (CTGGAGARACTAAGYCCTCC)/HpX1 (GAGGAATACTCATTGCGAAGGCGA) oligonucleotides. Each reaction consisted of $0.5 \mu \mathrm{L}$ of Taq polymerase DNA (2.5 units), $5 \mu \mathrm{L}$ of $10 \times$ CoralLoad PCR buffer (QIAamp, Qiagen) containing $\mathrm{MgCl} 2$ (1.5 mM), $2 \mu \mathrm{L}(2.5$ $\mathrm{mM}$ ) of dNTP (deoxyribonucleotides 5'-triphosphate-dATP, dCTP, dGTP, dTTP), $4 \mu \mathrm{L}$ of each oligonucleotide pair (10 pmol each), $33.5 \mu \mathrm{L}$ of ultrapure milli-Q water, and $5 \mu \mathrm{L}$ (50 ng) of Genomic DNA, totalling $50 \mu \mathrm{L}$ per reaction. Negative and positive controls were used with an aliquot of $H$. pylori DNA provided by Dr. Lucas Trevizani Rasmussen of the University of Sagrado Coração (Bauru, SP).

The amplified products were analyzed by electrophoresis on $1.6 \%$ agarose gel stained with ethidium bromide $(10 \mathrm{mg} / \mathrm{mL})$. Fragments with 150 base pairs were considered positive for the $\mathrm{HpX} / \mathrm{HpX} 1 \mathrm{PCR}$ primers.

\section{Data analysis}

The biopsy results and PCR amplifications were analyzed by descriptive statistics, Chi-square test $\left(\chi^{2}\right)$, and Pearson Contingency test $(P<0.05$ and $95 \%$ Confidence Interval). The analysis was performed through IBM SPSS (Statistical Package for the Social Sciences) version 25.0.

\section{RESULTS}

From the 113 investigated dyspeptic patients, 89 (78.8\%) were women, and $24(21.2 \%)$ were men. According to histopathological examination, the patients were often diagnosed with multiple outcomes in the endoscopy report $(n=155)$. From the 113 subjects, 77 patients had only one outcome and the remaining 36 exhibited two to four outcomes. We found that $83(53.5 \%)$ patients had gastritis, $16(10.3 \%)$ patients had esophagitis, $16(10.3 \%)$ had duodenitis, and $13(4.8 \%)$ presented gastric atrophy. An additional observation was that intestinal metaplasia, gastric or duodenal ulcer, gastric adenocarcinoma and xanthelasma were found in $2.6 \%, 1.9 \%, 1.2 \%$, and $0.6 \%$ of patients, respectively. Lastly, $17(12.4 \%)$ patients presented with normal biopsy results. (FIGURE 1). Excluding the two diagnosed cases of cancer, $96(86.5 \%)$ patients were classified as having low risk and $15(13.5 \%)$ as high risk for developing gastric adenocarcinoma $(\mathrm{n}=111)(P<0.0001)($ TABLE 1). 


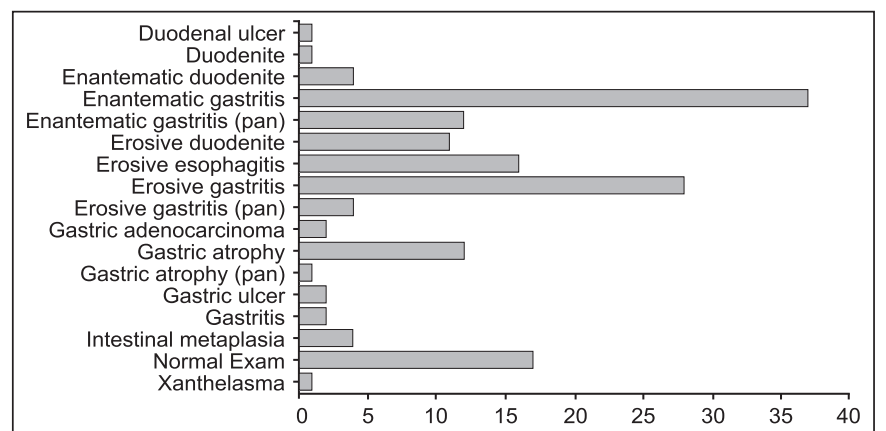

FIGURE 1. Detailed results according to the endoscopic report of 113 dyspeptic patients.

TABLE 1. Distribution by risk criteria for developing gastric adenocarcinoma according to histopathological diagnosis in 111 dyspeptic patients.

\begin{tabular}{lccccc}
\hline \multirow{2}{*}{ Endoscopic diagnosis } & \multicolumn{2}{c}{ Risk criteria $(\mathrm{n}=111)$} & \\
& $\mathrm{n}$ & $\%$ & $\mathrm{n}$ & $\%$ & \\
\hline Duodenite & 14 & 12.6 & 0 & 0.0 & $<0.0001$ \\
Esophagitis & 4 & 3.6 & 0 & 0.0 & \\
Gastric atrophy & 0 & 0.0 & 11 & 9.9 & \\
Gastric ulcer & 2 & 1.8 & 0 & 0.0 & \\
Gastritis & 58 & 52.3 & 0 & 0.0 & \\
Intestinal metaplasia & 0 & 0.0 & 4 & 3.6 & \\
Normal exam & 17 & 15.3 & 0 & 0.0 & \\
Xanthelasma & 1 & 0.9 & 0 & 0.0 & \\
\hline
\end{tabular}

Through PCR, we detected H. pylori infections in $75(66.4 \%)$ of the investigated patients. On gender basis, $59(78.7 \%)$ were women and $16(21.3 \%)$ were men. The data also depicted that $92 \%$ of infected patients were older than 44 years, confirming this age group, was the most prone to infections (61.1\%). Despite these numbers, we did not detect a statistically significant relationship between $H$. pylori infection and gender, age, educational level, and endoscopy diagnosis (TABLE 2).

Lastly, we verified the associations between $H$. pylori status determined by PCR and the risk for developing gastric adenocarcinoma in 111 patients. From the $73(65.77 \%)$ infected patients, $6(8.2 \%)$ had a high risk and $67(91.8 \%)$ had a low risk of developing gastric cancer. This difference in developing gastric adenocarcinoma between infected and non-infected patients was statistically significant $(P<0.05)$ (FIGURE 2$)$.

\section{DISCUSSION}

An increasing prevalence of $H$. pylori infection has been observed in developing countries, such as Brazil ${ }^{(3)}$. The infection prevalence in dyspeptic patients examined at the University Hospital was $61.1 \%$, which is in keeping with the infection rate data from other Brazilian states ${ }^{(31,32)}$.

The inflammatory process resulting from durable bacteria exposure in the gastric mucosa is directly related to the development of gastric cancer ${ }^{(20)}$. In this study, the presence of the bacteria was detected mainly in patients older than 44 years, showing that growing trend with age as a potential risk factor.

TABLE 2. Distribution by age, sex, educational level, endoscopic and molecular diagnoses of 113 dyspeptic patients.

\begin{tabular}{|c|c|c|c|c|c|c|c|}
\hline & \multicolumn{2}{|c|}{ Total } & \multicolumn{4}{|c|}{ H. pylori diagnosis $(\mathrm{n}=113)$} & \multirow{3}{*}{$P$-value } \\
\hline & $\mathrm{n}$ & $\%$ & Positive & $\%$ & Negative & $\%$ & \\
\hline & 113 & 100 & 75 & 66.4 & 38 & 33.6 & \\
\hline \multicolumn{8}{|l|}{ Age } \\
\hline $18-24$ & 10 & 8.8 & 8 & 80.0 & 2 & 20.0 & \multirow[b]{3}{*}{0.159} \\
\hline $24-34$ & 15 & 13.3 & 12 & 80.0 & 3 & 20.0 & \\
\hline $34-44$ & 18 & 15.9 & 14 & 77.8 & 4 & 22.2 & \\
\hline \multicolumn{8}{|l|}{ Sex } \\
\hline Female & 89 & 78.8 & 56 & 66.3 & 30 & 33.7 & \multirow{2}{*}{0.973} \\
\hline Male & 24 & 21.2 & 16 & 66.7 & 8 & 33.3 & \\
\hline \multicolumn{8}{|l|}{ Educational level } \\
\hline \multicolumn{8}{|l|}{ Biopsy } \\
\hline Duodenite & 16 & 10.3 & 13 & 81.3 & 3 & 18.8 & \multirow{9}{*}{0.339} \\
\hline Esophagitis & 16 & 10.3 & 11 & 68.8 & 5 & 31.3 & \\
\hline Gastric adenocarcinoma & 2 & 1.3 & 2 & 100.0 & 0 & 0.0 & \\
\hline Gastric atrophy & 13 & 8.4 & 5 & 38.5 & 8 & 61.5 & \\
\hline Gastric ulcer & 3 & 1.9 & 2 & 66.7 & 1 & 33.3 & \\
\hline Gastritis & 83 & 53.5 & 56 & 67.5 & 27 & 32.5 & \\
\hline Intestinal metaplasia & 4 & 2.6 & 2 & 50.0 & 2 & 50.0 & \\
\hline Normal exam & 17 & 11.0 & 13 & 76.5 & 4 & 23.5 & \\
\hline Xanthelasma & 1 & 0.6 & 1 & 100.0 & 0 & 0.0 & \\
\hline
\end{tabular}




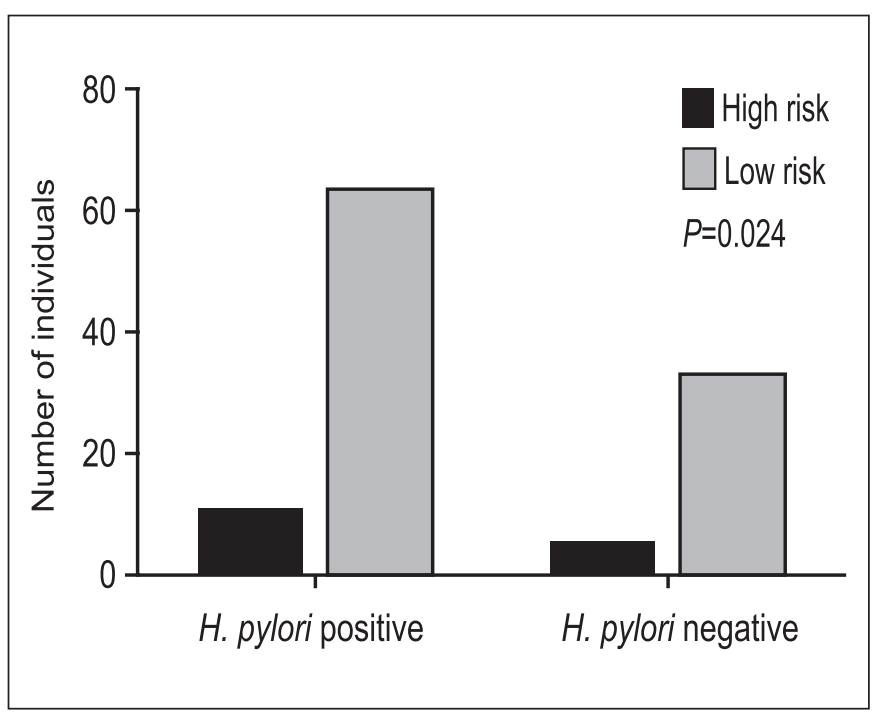

FIGURE 2. Individuals diagnosed with high and low risk disease to develop gastric adenocarcinoma according to molecular diagnosis of Helicobacter pylori (positive and negative). [Correlated population representation] $(\mathrm{n}=111)$.

This observation suggests that long-lasting periods of exposure to $H$. pylori may provoke tissue damage. An association of infection with the development of gastric adenocarcinoma was identified in this study ${ }^{(33)}$. However, no significant associations were found regarding sex, age, endoscopy diagnosis ${ }^{(34)}$ and educational levels ${ }^{(5)}$. Our study cohort was primarily composed of patients with low levels of education since the population served by public health system exhibit lower socioeconomic conditions $^{(35)}$.

H. pylori positive patients showed a higher frequency of gastritis $(67.5 \%)$ compared with uninfected patients $(32.5 \%)$. Depending on the severity and distribution of gastritis, the infection may result in hypo or hyperchlorhydria. Therefore, $H$. pylori infections are linked premature development of gastric and duodenal ulcers, which may progress to gastric adenocarcinoma ${ }^{(36)}$.

According to the risk criteria, $52.3 \%$ of patients were classified as having high risk developing gastric adenocarcinoma; of these, $8.2 \%$ were infected by $H$. pylori. Other risk factors, such as smoking and alcohol consumption are facilitators of $H$. pylori infection and consequently decrease the carcinogenesis threshold ${ }^{(30)}$. Thus, it is inconclusive whether the results for risk stratification may determine the likeliness of a patient developing gastric cancer, even if this infection is a determinant factor in 60 to $70 \%$ of cases $^{(29)}$.

The prevalence of gastric adenocarcinoma in this study $(1.3 \%)$ is in accordance with the low percentages found in other institutions in Brazil. In Teresina (Piauí State), Campelo e Lima (2012) observed a prevalence of 3.8\% (about 3.7 cases per year). In Santa Maria (Rio Grande do Sul State), Rampazzo et. al. (2012)

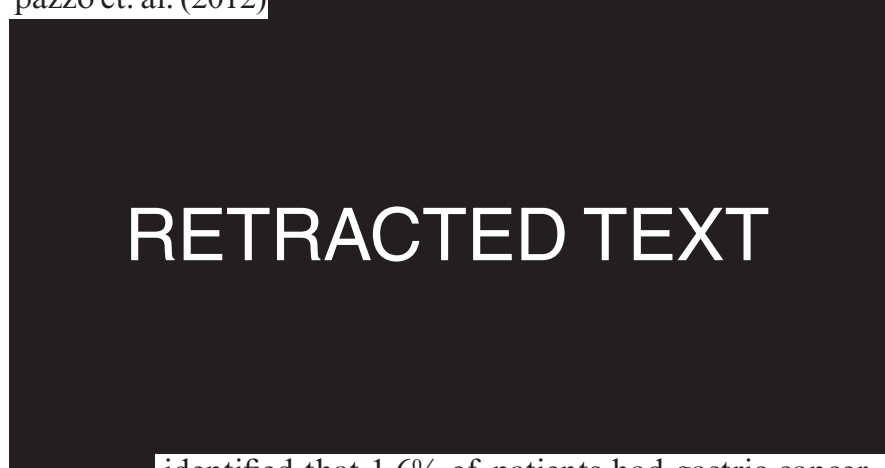

identified that $1.6 \%$ of patients had gastric cancer. Although the cases of gastric tumors are increasing and are linked to $H$. pylori infections, there is a lack of screening policies and secondary prevention approaches in Brazil. In contrast, developed countries such as Japan have public health policies aiming (within 50 years) to eradicate $H$. pylori infections and thereby, eliminate one of the risk factors for gastric adenocarcinoma development ${ }^{(37)}$.

\section{CONCLUSION}

This study identified high rates of $H$. pylori infection in a cohort from Brazil. The findings suggest that these infections are of clinical relevance for gastric adenocarcinoma development. In this scenario, there is an urgent need for implementing public policies and effective clinical prevention practices aiming at (a) controlling the transmission of H. pylori (b) avoiding long-term risk gastric malignancy development and (c) reducing public health system costs.

\section{Authors' contributions}

Borges SS: made all the statistical analyzes and wrote the scientific work. Ramos AFPL: made the DNA extraction. Moraes Filho AV and Braga CASB: helped in scientific writing. Carneiro LC: helped in DNA amplification. Barbosa MS: oriented in the statistical analyses and guided in the article writing.

\section{Orcid}

Stéfani Sousa Borges. Orcid: 0000-0003-4402-2175.

Amanda Ferreira Paes Landim Ramos. Orcid: 0000-00028148-4232.

Aroldo Vieira de Moraes Filho. Orcid: 0000-0003-23251374.

Carla Afonso da Silva Bitencourt Braga. Orcid: 0000-00026648-1674.

Lilian Carla Carneiro. Orcid: 0000-0003-4067-1506.

Mônica Santiago Barbosa. Orcid: 0000-0001-6964-5219. 
Borges SS, Ramos AFPL, Moraes Filho AV, Braga CASB, Carneiro LC, Barbosa MS. Prevalência da infecção por Helicobacter pylori em pacientes dispépticos e associação com fatores de riscos clínicos para o desenvolvimento de adenocarcinoma gástrico. Arq Gastroenterol. 2019. Ahead of print.

RESUMO - Contexto - No Brasil, particularmente nas áreas mais pobres, a prevalência da infecção por Helicobacter pylori pode variar até 90\%. Esses índices aumentam com o envelhecimento da população e são distintos entre as diferentes regiões do país. Podendo manifestar diferentes sintomatologias, essa infecção está diretamente relacionada com o desenvolvimento de patologias gástricas como gastrite leve a moderada, gastroenterites, úlcera péptica, metaplasia intestinal e principalmente, o câncer gástrico. Em 1994 a bactéria foi categorizada pela International Agency for Research on Cancer (IARC) como carcinógeno do Grupo 1 para adenocarcinoma gástrico, tipo de câncer que representa um importante problema de saúde pública, sendo o quarto tumor maligno mais comum e a segunda maior causa de mortes por câncer no mundo. Objetivo - Analisar a prevalência da bactéria em pacientes dispépticos e avaliar a associação de fatores de risco clínicos para desenvolvimento de adenocarcinoma gástrico. Métodos - Biópsias de tecido gástrico coletadas de 113 pacientes dispépticos, atendidos no Hospital das Clínicas da Universidade Federal de Goiás, foram submetidas a diagnóstico molecular por meio de Reação em Cadeia da Polimerase, para identificação da infecção por Helicobacter pylori, e exame histopatológico, para avaliar o risco clínico de desenvolvimento de adenocarcinoma gástrico. Resultados - Foram diagnosticadas 75 (66,4\%) amostras positivas para infecção por Helicobacter pylori, sendo 69 indivíduos maiores de 44 anos de idade. A prevalência do adenocarcinoma gástrico nesse estudo foi de 1,3\% e dentre os pacientes positivos para a infecção bacteriana seis $(8,2 \%)$ possuem alto risco e $67(91,8 \%)$ baixo risco de desenvolver esse tipo de câncer $(P<0,05)$. Conclusão - Esse estudo mostra uma alta prevalência da infecção por H. pylori na população estudada e identifica sua intrínseca contribuição para inflamações gástricas, que a longo prazo se manifestam em fatores clínicos de alto risco para o desenvolvimento de adenocarcinoma gástrico.

DESCRITORES - Dispepsia. Neoplasias gástricas. Gastroenteropatias. Bactérias.

\section{REFERENCES}

1. Marshall BJ, Warren JR. Unidentified Curved Bacilli in the Stomach of Patients With Gastritis and Peptic Ulceration. Lancet. 1984;323:1311-5.

2. Brown LM. Helicobacter pylori: Epidemiology and routes of transmission. Epidemiol Rev. 2000;22:283-97.

3. Hunt RH, Xiao SD, Megraud F, Leon-Barua R, Bazzoli F, van der Merwe S, et al. Helicobacter pylori in developing countries. World Gastroenterology Organisation Global Guideline. J Gastrointest Liver Dis. 2011;20:299-304.

4. Frenck RW, Clemens J. Helicobacter in the developing world. Microbes Infect. 2003;5:705-13.

5. Basílio ILD, Catão MDFC Carvalho JDDS, Freire-Neto FP, Ferreira LC, Jerônimo SMB. Risk factors of Helicobacter pylori infection in an urban community in Northeast Brazil and the relationship between the infection and gastric diseases. Rev Soc Bras Med Trop. 2018;51:183-9.

6. Toscano EP, Madeira FF, Dutra-Rulli MP, Gonçalves LOM, Proença MA, Borghi VS, et al. Epidemiological and Clinical-Pathological Aspects of Helicobacter pylori Infection in Brazilian Children and Adults. Gastroenterol Res Pract. 2018;2018:1-8.

7. Mitchell HM, Li YY, Hu PJ, Liu Q, Chen M, Du GG, et al. Epidemiology of Helicobacter-Pylori in Southern China - Identification of Early-Childhood as the Critical Period for Acquisition. J Infect Dis. 1992;166:149-53.

8. Lopes AI, Vale FF, Oleastro M. Helicobacter pylori infection - Recent developments in diagnosis. World J Gastroenterol. 2014;20:9299-313.

9. Junqueira ACM, Ratan A, Acerbi E, Drautz-Moses DI, Premkrishnan BNV, Costea PI, et al. The microbiomes of blowflies and houseflies as bacterial transmission reservoirs. Sci Rep. 2017;7:1-15.

10. Zhu Y, Zhou X, Wu J, Zhang G. Risk factors and prevalence of Helicobacter pylori infection in high incidence area of gastric carcinoma. J Gastroenterol Hepatol [Internet]. 2013;28:551.

11. Ding Z, Zhao S, Gong S, Li Z, Mao M, Xu X, et al. Prevalence and risk factors of Helicobacter pylori infection in asymptomatic Chinese children: a prospective, cross-sectional, population-based study. Aliment Pharmacol Ther. 2015;42:1019-26.

12. Ali A, Riaz Ahmad M, Iqbal Z, Basit A. Identification of the Risk Factors Associated with Helicobacter pylori Infection in Lahore, Pakistan. J Biom Biostat. 2017;08:1-5.

13. Bello AK, Umar AB, Borodo MM. Prevalence and Risk Factors of Helicobacter pylori Infection in Gastroduodenal Diseases in Kano, Nigeria. African J Med Heal Sci. 2018;17:41-6.

14. Agbor NE, Esemu SN, Ndip LM, Tanih NF, Smith SI, Ndip RN. Helicobacter pylori in patients with gastritis in West Cameroon: prevalence and risk factors for infection. BMC Res Notes. 2018;11:559.

15. Smith S, Jolaiya T, Fowora M, Palamides P, Ngoka F, Bamidele M, et al. Clinica and Socio- Demographic Risk Factors for Acquisition of Helicobacter pylori Infection in Nigeria. 2018;19:1851-7.

16. Hasosah M, Satti M, Shehzad A, Alsahafi A, Sukkar G, Alzaben A, et al. Prevalence and risk factors of helicobacter pylori infection in saudi children: A three-year prospective controlled study. Helicobacter. 2015;20:56-63.

17. Laszewicz W, Iwańczak F, Iwańczak B. Seroprevalence of Helicobacter pylori infection in Polish children and adults depending on socioeconomic status and living conditions. Adv Med Sci. 2014;59:147-50.
18. Levenstein S, Rosenstock S, Jacobsen RK, Jorgensen T. Psychological stress increases risk for peptic ulcer, regardless of Helicobacter pylori infection or use of nonsteroida anti-inflammatory drugs. Clin Gastroenterol Hepatol. 2015;13:498-506.

19. Eusebi LH, Zagari RM, Bazzoli F. Epidemiology of Helicobacter pylori Infection. Helicobacter. 2014;19(S1):1-5.

20. Campelo JCL, Lima LC. Perfil Clinicoepidemiológico do Câncer Gástrico Precoce em um Hospital de Referência em Teresina, Piauí. Rev Bras Cancerol. 2012;58:15-20.

21. Brasil. Ministério da Saúde. Diretrizes Diagnósticas e Terapêuticas - Adenocarcinoma de Estômago. CONITEC. Brasília - DF: CONITEC/Comissão Naciona de Incorporação de Tecnologias no SUS; 2017. 1-24 p.

22. Souza IKF, Silva AL, Araújo AJ, Santos FCB, Mendonça BPCK. Qualitative analysis of anatomopathological changes of gastric mucosa due to long term therapy with proton pump inhibitors: experimental studies X clinical studies. Arq Bras Cir Dig. 2013;26:328-34.

23. Yakoob J, Fatima SS, Abbas Z, Mustafa SF, Khan HAR, Raghib MF, et al. Distribution of gastric carcinoma in an area with a high prevalence of Helicobacter pylori. Turkish J Gastroenterol. 2017;28:98-103.

24. IARC. World Cancer Report 2014. Edited by Stewart BW, Wild CP; 2014. ISBN 978-92-832-0429-9.

25. Ferlay J, Shin HR, Bray F, Forman D, Mathers C, Parkin DM. Estimates of worldwide burden of cancer in 2008: GLOBOCAN 2008. Int J Cancer. 2010;127:2893-917.

26. Jemal A, Ward E, Thun M. Declining death rates reflect progress against cancer. PLoS One. 2010;5:1-10.

27. Murray CJL, Vos T, Lozano R, Naghavi M, Flaxman AD, Michaud C, et al Disability-adjusted life years (DALYs) for 291 diseases and injuries in 21 regions, 1990-2010: A systematic analysis for the Global Burden of Disease Study 2010. Lancet. 2012;380:2197-223.

28. Choi IJ, Kook MC, Kim Y Il, Cho SJ, Lee JY, Kim CG, et al. Helicobacter pylori Therapy for the Prevention of Metachronous Gastric Cancer. N Engl J Med. 2018:378:1085-95.

29. Fock KM. Review article: The epidemiology and prevention of gastric cancer Aliment Pharmacol Ther. 2014;40:250-60.

30. Zhang RG. Role of Helicobacter pylori infection in pathogenesis of gastric carcinoma. World J Gastrointest Pathophysiol. 2016;7:97.

31. Zaterka S, Eisig JN, Chinzon D, Rothstein W. Factors related to Helicobacter pylori prevalence in an adult population in Brazil. Helicobacter. 2007;12:82-8.

32. Rodrigues M, Queiroz D, Rodrigues R, Rocha A, Luza C, Braga L. Prevalence of Helicobacter pylori infection in Fortaleza, Northeastern Brazil. Rev Saude Publica. 2005;39:8047-9

33. Wang F, Meng W, Wang B, Qiao L. Helicobacter pylori-induced gastric inflammation and gastric cancer. Cancer Lett. 2014;345:196-202.

34. Rampazzo A, Mott GL, Fontana K, Fagundes RB. Gastric adenocarcinoma trends in the central region of Rio Grande do Sul (Southern Brazil): what has changed in 25 years? Arq Gastroenterol. 2012;49:178-83.

35. Mesa-Lago. O sistema de saúde brasileiro: seu impacto na pobreza e na desigualdade. Nueva Sociedad, 2007;1992:115-131.

36. Wroblewski LE, Peek RM, Wilson KT. Helicobacter pylori and Gastric Cancer: Factors That Modulate Disease Risk. Clin Microbiol Rev. 2010;23:713-39.

37. Asaka M. A new approach for elimination of gastric cancer deaths in Japan. Int J Cancer. 2013;132:1272-6. 